\title{
Pola Asuh Demokratis sebagai Upaya Menumbuhkan Kemandirian Anak di Panti Asuhan Dewi Aminah
}

\author{
A. Tabi'in \\ Jurusan PIAUD, Fakultas Tarbiyah dan Ilmu Keguruan, LAIN Pekalongan \\ e-mail:_abmadtabiin6@gmail.com
}

\begin{abstract}
ABSTRAK. Penelitian ini dilatarbelakangi dari ketertarikan terhadap kemandirian anak yang hidup di Panti Asuhan Dewi Aminah Kota Pekalongan yang keseharian diasuh oleh orang tua ganti karena anak-anak yang di panti asuhan adalah anak yatim dan yatim piatu yang sudah tidak memiliki keluarga. Penelitian ini bertujuan untuk mengetahui kemandirian anak usia dini 4-6 tahun yang hidup di panti asuhan, kecenderungan pola demokratis yang diterapkan di panti menjadi faktor utama anak-anak memiliki sifat kemandirian dalam menjalani kehidupan sehari-hari. Metode yang digunakan dalam research ini adalah pendekatan kualitatif deskriptif dengan teknik pengumpulan data menggunakan wawancara, observasi, dan dokumentasi. Setelah itu diproses melalui triangulasi data. Berdasarkan hasil penelitian anak-anak yang hidup di panti asuhan mempunyai kemandirian (autonomi) yang baik, dengan kemandirian ini anak akan terhindar dari sifat ketergantungan pada orang lain, yang terpenting adalah menumbuhkan keberanian dan motivasi anak untuk terus mengekspresikan pengetahuan baru. Hal ini tidak terlepas karena panti asuhan mengasuh anak menggunakan pola asuh demokratis, Pola asuh demokratis menjadikan karakteristik anak usia dini yang mandiri, serta dapat mengontrol dirinya untuk membangun hubungan baik dengan teman, mampu menghadapi stress, mempunyai minat terhadap hal-hal baru dan koperatif terhadap orang lain. Pola asuh tersebut menjadi pendorong terciptanya anak usia dini yang ada di panti asuhan guna memiliki kemandirian, salah satu kemandirian tersebut terlihat ketika anak-anak memakai baju, mandi, makan, bermain dan mampu bersosialisasi dengan kawan sejawat.
\end{abstract}

Kata Kunci:Panti Asuhan Demokratis, Kemandirian, Anak

ABSTRACT. This research is motivated by an interest in the independence of children living in orphanages that are taken care of daily by the changing parents because the children in the orphanage are orphans and orphans who do not have a family. This study aims to determine the independence of children aged 4-6 years who live in an orphanage, the tendency of democratic patterns applied in the home is the main factor of children having the nature of independence in living everyday life. The method used in this research is a descriptive qualitative approach with data collection techniques using observation, interviews, and documentation. Then it is processed through data triangulation. Based on research results Children who live in orphanages have good independence (autonomy), with this independence children will avoid the nature of dependence on others, and the most important thing is to grow courage and motivation in children to continue to express new knowledge. This is inseparable because parenting orphanages use democratic parenting, Democratic parenting produces characteristics of children who are independent, can control themselves, have good relationships with friends, are able to deal with stress, have an interest in new things and are cooperative towards people -other people. The pattern of fostering is a driving force for the creation of early childhood in the orphanage has independence, one of these independence seen when children wear clothes, bathing, eating, playing and able to socialize with colleagues.

Keywords: Orphanage, Democratic Parenting, Independence, Early Childhood 


\section{PENDAHULUAN}

Pendidikan anak usia dini (PAUD) merupakan jenjang sebelum pendidikan dasar dimana anak dibina sejak lahir sampai dengan usia enam tahun. Pendidikan PAUD ini diberikan dengan cara memberikan rangsangan pendidikan untuk menstimulasi pertumbuhan dan perkembangan baik jasmani, maupun rohani supaya anak-anak mempunyai kesiapan dalam menempuh pendidikan di jenjang berikutnya (Novan Ardy Wiyani \& Barnawi: 2014).

Anak-anak merupakan tonggak estafet bangsa, untuk itu membutuhkan pendidikan yang mempunyai kualitas yang baik supaya tercapai nawacita bangsa yang baik. Dengan demikian untuk mendapat kualitas anak-anak yang baik tentunya anak harus distimulasi dengan menumbuhkan aspek-aspek perkembangan anak, hal ini dapat dimulai dari pendidikan keluarga dan PAUD. Salah satu indikator perkembangan anak usia dini yaitu pada aspek kemandirian. yamin (2012:60) menyatakan bahwa aspek perkembangan kemandirian anak merupakan hasil dari kegiatan yang menunjang anak dalam ranah normative, yang sesuai dengan cita-cita kehidupan manusia. Pendapat lain yaitu (Sriyani and Sariah 2019) Orang tua merupakan guru atau pendidik paling dasar dalam menumbuhkan kepribadian anak guna menciptakan kepribadian anak yang di inginkan dengan cara pembiasaan dalam kehidupan sehari-hari melalui media lingkungan sekitar anak dan keluarganya. Pemberian pola asuh yang baik dan benar orangtua dan guru dapat merangsang anak untuk menjadi pribadi yang baik dan mandiri (Masni, n.d.). peran keluarga sangatlah penting dalam membuat situasi dan kondisi yang memuat iklim dalam keseharian anakanak untuk memperdalam dan memperluas makna-makna kehidupan yang esensial.

Pendapat lain (Muhadi 2015) kemandirian seorang anak akan tercipta ketika orangtua mempunyai peran yang sangat signifikan dalam menumbuhkan kemandirian anak. Pola asuh yang demokratis disini mempunyai peranan sangat penting karena pola asuh tersebut merupakan gambaran tentang bagaimana sikap dan tingkah laku orang tua terhadap anak-anaknya dalam berinteraksi dalam kehidupan sehari-hari, kegiatan pengasuhan ini mengasah kemampuan personal anak dalam melakukan kegiatan yang ada di lingkungan keluarga, jika ini berhasil di terapkan oleh orang tua tentunya ini akan mendorong anak-anak dalam kemandirian.

Kemandirian anak tidak semata-mata tercipta secara alami karena tanpa adanya sentuhan pendidikan yang dilakukan oleh orang tua atau pengasuh tidak dapat menjadikan anak hidup dalam kemandirian. Kondisi seperti ini disebabkan langsung akibat dari pola asuh yang dilakukan oleh orang tuanya dalam mendidik serta mengasuh buah hatinya. Kemandirian anak-anak tercipta karena orang tua sudah terbiasa membiasakan untuk melakukan sesuatu dalam kehidupan seharihari secara mandiri dengan arahan dan sentuhan ketika orang tua mengasuh contoh sederhana, anak dibiasakan untuk mencoba makan sendiri tanpa bantuan orang tua, memakai celana dan baju, membersihkan tempat tidur dan membersihkan mainan setelah digunakan. Orang tua juga mengajarkan pada anak untuk membantu orang tua secara sederhana yaitu menyiram tanaman. Dengan begitu selain orang tua mengajarkan kemandirian pada anak juga sekaligus menerapkan pola asuh demokratis pada anak-anaknya, dikarenakan dalam pengasuhan ini orang tua menjalin komunikasi terbuka serta memberikan kebebasan pada anak untuk melakukan sesuatu sesuai dengan rambu-rambu yang dapat dikerjakan oleh anak, akan tetapi dalam memberikan kebebasan orang tua wajib memantau sehingga anak masih dalam pengawasan dan dengan harapan besar anak terbiasa menjadi mandiri serta dapat mengambil keputusan yang dilakukan oleh anak.

Pola asuh adalah interaksi antara orang tua dan anak selama mengadakan proses pembinaan atau pengasuhan, artinya bahwa selama proses interaksi pembinaan yang dilakukan 
orangtua mempunyai peranan sangat penting dalam pembentukan kepribadian anak, mendidik, membimbing. Membuat disiplin serta melindungi anak untuk mencapai kedewasaan sesuai dengan norma-norma yang ada dalam masyarakat. Dalam mengasuh anaknya, orang tua cenderung menggunakan pola asuh tertentu (A. Tabi'in 2017). Penggunaan pola asuh tertentu ini memberikan sumbangan dalam mewarnai perkembangan terhadap bentuk-bentuk perilaku sosial tertentu pada anaknya, sedangkan bagi anak yang sudah tidak mempunyai orang tua yang kemudian dititipkan pada sebuah panti tentunya pengelola panti menjadi yang bertanggung jawab dalam mengasuh anak-anak yatim tersebut.

Membentuk kemandirian anak tidak semudah membalikkan telapak tangan dan bukan terjadi secara instan, karena kemandirian dipengaruhi banyak faktor dalam pembentukannya. Salah satu hal yang paling dominan dalam membentuk kemandirian anak yaitu adalah pola asuh orang tuanya. Pola asuh yang diterapkan oleh orang tuanya menjadi salah satu faktor penunjang dalam menumbuhkan sikap kemandirian anak, orang tua memiliki peranan penting dalam mengasuh, membina, membantu serta mengarahkan anak-anaknya untuk memiliki sikap kemandirian itu tidak lain karena masa anak-anak adalah masa dimana anak mempunyai perkembangan yang sangat penting dalam proses perkembangan kemandirian (Umairoh 2018). Selain itu tidak kalah pentingnya dalam menumbuhkan kemandirian anak-anak adalah pihak panti, pihak ini juga mempunyai peranan yang tidak kalah penting karena anak-anak dalam kesehariannya di panti asuhan akan mendapatkan pengalaman-pengalaman empiris untuk mandiri.

Kemandirian anak usia dini tidak akan muncul pada anak tanpa adanya stimulus dari pengasuh atau pendamping anak hal ini sejalan dengan hasil research yang di kemukakan oleh (Umairoh 2018), bahwa anak perlu bimbingan yang intensif supaya anak dapat mencapai kemandirian. Pendapat lain terkait kemandirian pada anak anak usia dini bahwa pola asuh demokratis merupakan salah satu faktor yang penting dalam menumbuhkan sikap kemandirian. Karena pola asuh akan mempengaruhi aktivitas anak dalam kehidupan sehari-hari. berbeda ketika orang tua menggunakan pola asuh selain demokratis anak cenderung akan apatis terhadap lingkungan sekitar anak dan cenderung mempunyai ketergantungan dengan keluarga terutama pada orang tua anak.

Sejalan dengan itu panti asuhan merupakan salah satu wadah atau tempat bagi anak yatim atau tidak berayah lagi (karena ditinggal mati) dan piatu atau sudah tidak berayah dan beribu lagi di Indonesia lembaga ini dipelopori oleh organisasi keagamaan atau organisasi perorangan yang berfungsi untuk memberikan perlindungan terhadap hak-hak anak seperti yatim maupun piatu. (Rianti and Ifdil 2018). Lembaga ini berperan selayaknya orang tua terhadap anak yaitu menjaga, mengasuh dan membimbing mereka agar bertanggung jawab serta memiliki akhlak yang baik agar bermanfaat dimasa depan (Lestari, Prantiasih, and Hady: 2018).

Anak usia dini yang terbiasa hidup bersama orang tua dan hidup di panti tentunya mempunyai permasalahan yang berbeda, anak-anak panti diawal mula bergabung masih seperti anak pada umumnya memiliki kecenderungan yang minta diperhatikan, tentunya ini membuat panti agak kerepotan mengingat yang diurus tidak anak satu atau dua orang melainkan banyak anak. Hal ini yang kemudian melatarbelakangi Panti Asuhan Dewi Aminah untuk melakukan tindakan yaitu mengubah pola asuh menjadi demokratis dengan mengedepankan aspek psikologis anak-anak yang rata-rata masih anak usia dini. Ada beberapa hal yang melatarbelakangi anak untuk mandiri. Pertama, Lingkungan rumah atau keluarga (internal) dan lingkungan masyarakat (eksternal) mempunyai peran besar dalam menentukan kepribadian anak yaitu kemandirian. 
Kedua, Pola Asuh orang tua, orang atau pengasuh di panti memiliki peran yang sangat penting dan mempunyai andil besar dalam menumbuhkan sikap kemandirian pada anak-anaknya. Ketiga, Pendidikan. Proses belajar mengajar atau mendidik anak salah satu contributor utama dalam melatarbelakangi terbentuknya kemandirian anak-anak. Hal itu tercipta melalui, interaksi sosial, interaksi ini dapat melatih anak dalam menyesuaikan diri mereka pada lingkungan sekitar, serta melatih tanggung jawab anak atas apa yang mereka perbuat, selain itu yaitu intelegensi, intelegensi juga merupakan faktor yang urgen dalam membentuk serta mempengaruhi kemandirian anak terutama dalam aspek pengambilan keputusan, menentukan sikap dalam bergaul, menyesuaikan diri serta mampu dalam mengambil keputusan, hal-hal seperti itu bisa dilatih ketika orang tua atau pengasuh mampu menerapkan pola asuh yang demokratis serta menjalin komunikasi terbuka pada anak-anaknya.

Panti asuhan pada hakikatnya membantu anak-anak yatim untuk belajar menjadi anak yang mandiri bukanlah hal yang mudah, apalagi tanpa dukungan langsung dari orangtua. Namun, bagi anak yang tidak tinggal dengan orangtua, kemandirian merupakan suatu keharusan yang harus mereka miliki, seperti halnya anak-anak yang tinggal di panti asuhan. Tuntutan keadaan membuat mereka mau tak mau harus bisa menjadi anak-anak yang mandiri, yang harus bisa mengurus diri sendiri dan sebisa mungkin tidak terlalu bergantung kepada orang lain. Ketiadaan orangtua kandung di panti asuhan membuat mereka tidak bisa bermanja-manja, seperti anak-anak kebanyakan, sebab semakin rendah tingkat ketergantungan mereka terhadap orang lain, akan membuat kemandirian mereka semakin tinggi.

Sejalan dengan pendapat Bahri (2014:51) Pola asuh orang tua adalah suatu kebiasaan bagaimana orang tua mengasuh anak secara continue atau berkesinambungan. Mengasuh atau membimbing anak merupakan hal terpenting bagi seorang ibu dan ayah karena mengasuh yaitu mempunyai makna menjaga, merawat dan memberi edukasi. Orang tua yang baik ketika mengasuh anak dengan cara demokratis dengan hal itu tentunya akan membuat anak merasa nyaman, terlindungi serta anak merasa diperhatikan oleh kedua orang tua nya. Kepribadian yang proporsional, kemandirian serta mampu peka terhadap lingkungan sekitar akan tercipta manakala pola asuh tersebut berjalan dengan baik dalam keseharian. Hal ini sangat berbeda ketika orang tua atau pengasuh menerapkan pola asuh secara otoriter, karena pola asuh otoriter mempunyai kecenderungan anak-anak yang diasuh harus mampu mengikuti perintah orang tua nya. Pola asuh ini tentunya dapat membuat anak-anak mengalami penolakan dari perintah orang tua dan ini akan membuat anak-anak menjadi pribadi yang tidak mandiri, atau hanya kelihatan mandiri karena faktor tekanan yang diakibatkan oleh pola asuh orang tua nya, kecenderungan yang terjadi anak-anak kurang memperdulikan orang yang ada di sekitarnya (Agus, 2012:79).

Panti asuhan Dewi Aminah adalah salah satu lembaga sosial yang mendidik dan membina anak asuh yang memiliki masalah sosial, seperti kemampuan ekonomi, kurangnya salah satu dari kepala keluarga atau keduanya, sehingga lingkungan keluarga tidak lagi dapat memberikan solusi terhadap permasalahan kehidupan. Yayasan ini berfungsi sebagai lembaga sosial dimana dalam kehidupan sehari-hari, anak diasuh, dididik, dibimbing, diarahkan, diberi kasih sayang, dicukupi kebutuhan sehari-hari.

\section{METODE}

Metode yang digunakan dalam penelitian ini adalah metode deskriptif kualitatif, yang berupa kata-kata tertulis atau lisan tentang orang-orang dan perilaku yang dapat diamati (Moleong, 2005) mulai dari ketua panti, ustad/ustadzah/guru, pengasuh di panti asuhan yang ada di Kota 
Pekalongan. Penelitian ini diharapkan memberikan pandangan atau gambaran yang menguraikan atas sesuatu keadaan (Rony Kountur, 2005: 105) yang berkaitan dengan pola asuh demokratis pada anak usia dini dalam menumbuhkan kemandirian. Peneliti melakukan tahapan penelitian yang mengacu pendapatnya Endang S. Sedyaningsih Dr. (2006) dalam Asep Suryana (2007:5) yaitu dimulai dari menentukan permasalahan kemudian melakukan studi literatur dari referensi tentang pola asuh demokratis dalam menumbuhkan sikap kemandirian anak usia dini, dilanjutkan menetapkan lokasi penelitian, studi pendahuluan, penetapan teknik pengumpulan data (wawancara, dokumentasi, observasi), analisis data dan validasi data. Hasil penelitian ini diharapkan dapat memecahkan rumusan masalah yaitu penggunaan pola asuh demokratis dalam menumbuhkan sikap kemandirian anak usia dini yang tidak memiliki ayah dan ibu atau yatim/yatim piatu. Adapun sumber data dalam penelitian ini adalah kepala panti yang diwawancarai, anak-anak yang diobservasi, pengasuh panti yang diwawancarai dan diobservasi, yayasan dan karyawan yang penulis tentukan sendiri berdasarkan pertimbangan dari ketua panti serta yayasan, dokumen-dokumen, dan arsip-arsip di sekolah yang mendukung sumber data utama.

Metode pengumpulan data, peneliti menggunakan dokumentasi yang sesuai dengan arah penelitian, kemudian interview, serta observasi yang mendalam. Data-data yang di peroleh peneliti dari interview, dokumentasi serta observasi kemudian diolah dan dipadukan. Hal ini mempunyai tujuan untuk menghasilkan data-data yang akurat dan mampu untuk di pertanggungjawabkan keasliannya. Analisis data lakukan sejak dimulainya penelitian sampai penyusunan naskah akhir penelitian. Konsep yang digunakan dalam penelitian ini analisis mengalir (flow model analysis), yaitu konsep analisa yang meliputi tahapan-tahapan sebagai berikut; display data, pengambilan kesimpulan dan mengverifikasi (Huberman, 1992). Dalam hal ini peneliti melakukan pemeriksaan secara seksama pada kriteria tingkat kepercayaan (credibility). Melalui kriteria tersebut kemudian menggunakan triangulasi data atau pengambangan data melalui analisis-analisis yang mendalam (Moleong, 2005). Pada research ini, penulis menggunakan triangulasi diantaranya yaitu: Pertama, , triangulasi metode dengan menggunakan berbagai metode pengumpulan data untuk menggali data yang sejenis. Kedua, triangulasi sumber dengan membandingkan informasi yang dikatakan subyek dalam penelitian ini

\section{HASIL dan PEMBAHASAN}

\section{Pola Asuh Demokratis}

Pola asuh dilihat dari segi bahasa terdiri dari kata "pola" dan "asuh" . "pola" berarti model, sistem, cara kerja, bentuk (struktur yang tetap). (Depdiknas, 2001) Sedangkan kata "asuh" mengandung arti menjaga, merawat, mendidik anak agar dapat berdiri sendiri. Adapun pengertian pola asuh itu sendiri adalah suatu proses yang dilakukan orang tua untuk mendidik anak, membimbing dan mendisiplinkan serta melindungi anak untuk mencapai kedewasaan dengan norma-norma yang ada di masyarakat.

Menurut (Idris 2014). pola pengasuhan ada pemberian rangsangan pertama dari orang tua pada anak anaknya, sedangkan pendapat lainnya yang dikemukakan oleh Fathi bahwa pola asuh meliputi komunikasi dan interaksi antara anak dan kedua orang tua nya dalam memenuhi kebutuhan anak yang meliputi kebutuhan fisik dan psikis (Fathu: 2011). Pendapat lain yaitu Khon dalam zahroh (2011) yaitu sikap bagaimana ketika orang tua membina dan berinteraksi dengan anaknya. Sikap ini orang tua ketika memberi pengetahuan tentang aturan-aturan, memberi sanksi pada anak-anaknya. Pola asuh orang tua terdiri berbagai macam dan mempunyai dampak yang 
berbeda-beda, yaitu: pola asuh demokratis dimana sebagai orang tua menjalankan pembinaan pada anak secara terbuka dan adil hal ini sangat positif diterapkan sebagai upaya menumbuhkan kemandirian anak-anaknya. Selanjutnya pola asuh otoritatif, dimana kehendak orang tua bisanya harus dipenuhi kepada anak-anaknya, hal ini kurang baik jika ini terjadi karena mempunyai dampak buruk terhadap anak-anak pada kehidupan yang akan datang. Pola asuh yang selanjutnya yaitu pola asuh permisif, dimana orang tua mendidik anak-anaknya dengan pembinaan yang bebas tidak banyak diperhatikan apa yang anak kerjakan atau cuek apa yang dilakukan anak-anak dalam kesehariannya Thoha, 1996).

Pola asuh demokratis adalah pola pengasuhan dimana orang tua menstimulasi anakanaknya untuk lebih mandiri, akan tetapi selalu memberikan batasan atau aturan serta mengontrol perilaku anak. Orang tua selalu bersikap bumble, mengasuh dengan penuh kasih sayang serta penuh perhatian. Orang tua harus memberi ruang kepada anak untuk membicarakan apa yang mereka inginkan atau harapan dari orang tuanya. Adapun pengertian lain dari bahwa pola asuh demokratis yaitu dimana orang tua melakukan pembinaan pada anak sebagai upaya menjadikan anak yang mempunyai kepribadian, sifat, moral yang baik serta mampu memiliki sikap yang rasional (Al. Tridhonanto : 2014).

Dari beberapa pengertian tersebut dapat diketahui bahwa pola asuh merupakan hal yang sangat urgen dalam menentukan kepribadian anak. Pengasuhan atau pembinaan yang dilakukan oleh orang tua menjadi tonggak dalam peletakan dasar pembinaan yang berkaitan dengan nilainilai yang ada di masyarakat yang meliputi nilai agama, nilai sosial, nilai budaya, hal ini penting supaya anak dapat menjadi pribadi yang baik serta mempersiapkan anak-anak dalam mengarungi kehidupan di masa yang akan datang.

Sejalan dengan teori tentang kemandirian anak, bahwa kemandirian anak akan tercipta manakala ada perpaduan antara pengasuhan demokratis terhadap anak yang kemudian memunculkan sikap kemandirian pada anak-anak panti asuhan. Karena melalui pengasuhan yang demokratis dan anak mampu bersosialisasi pada teman-teman sebayanya anak akan mendapatkan pengalaman belajar yang riil dan kemudian mampu mengambil keputusan yang tepat.

\section{Kemandirian Anak Usia Dini}

Kemandirian merupakan kemampuan anak dalam melakukan aktivitas tanpa ketergantungan kepada orang lain, sebagai mana pendapat Subroto mengatakan bahwa kemandirian itu kemampuan seorang anak dalam melakukan kegiatan sehari-hari tanpa membebani atau meminta bantuan orang lain dalam berbagai hal. Astiti juga mengartikan bahwa kemandirian bisa menjalani kehidupan tanpa merepotkan orang lain akan tetapi anak perlu di berikan stimulan atau contoh dalam lingkup kemandirian sehari-hari secara mudah dan sederhana.

Dengan demikian, kemandirian anak usia dini dapat diartikan sebagai karakter yang dapat menjadikan anak yang berusia 0-6 tahun dapat berdiri sendiri, tidak tergantung dengan orang lain, khususnya orang tuanya. Menurut Bachrudin Mustafa dalam wiyani 2013, kemandirian adalah kemampuan untuk mengambil pilihan dan menerima konsekuensi yang menyertainya. Kemandirian kepada anak-anak terwujud jika mereka menggunakan pikirannya sendiri dalam mengambil berbagai keputusan, dari memilih perlengkapan belajar yang ingin digunakannya, memilih teman bermain sampai hal-hal yang relatif lebih rumit dan menyertakan konsekuensikonsekuensi tertentu yang lebih serius.

Lebih lanjut, Mustafa mengungkapkan bahwa tumbuhnya perkembangan pada anak-anak bersamaan dengan munculnya rasa takut atau kehawatiran dalam berbagai bentuk dan intensitas 
yang berbeda-beda. Rasa takut (kehawatiran) dalam takaran yang wajar dapat berfungsi sebagai emosi perlindungan (protective emotion) bagi anak-anak yang memungkinkan dirinya mengetahui kapan waktunya meminta perlindungan kepada orangtuanya atau orang dewasa. Sementara menurut Syamsu Yusuf, kemandirian yang dapat disebut juga dengan istilah autonomi merupakan karakteristik dari kepribadian yang sehat (healthy personality). Kemandirian individu tercermin dalam cara berfikir dan bertindak, mampu mengambil keputusan, mengarahkan dan mengembangkan diri serta menyesuaikan diri secara konstruktif dengan norma yang berlaku di lingkungannya.Dari penjelasan Mustafa dan Syamsu Yusuf di atas, dapat ditarik kesimpulan bahwa kemandirian yang akan dibentuk oleh orang tua dan guru adalah kemandirian yang menjadikan anak usia dini:

a. Anak memiliki kemampuan dalam menentukan pilihannya sendiri.

b. Anak mampu memutuskan sesuatu dengan pilihanya sendiri

c. Anak dapat bertanggung jawab atas apa yang dipilihnya serta mengetahui konsekuensi atas apa yang dipilihnya.

d. Anak memiliki rasa percaya diri yang baik.

e. Anak mampu mengarahkan diri secara sederhana dan sesuai kemampuannya.

f. Anak dapat menyesuaikan diri dengan lingkungan sekitarnya.

g. Anak berani mengambil keputusannya.

h. Anak tidak memiliki ketergantungan dengan orang lain.

i. Anak memiliki kemandirian belajar.

Winnicot mengungkapkan bahwa anak usia dini belajar untuk tumbuh kembang dan berkembang secara cepat dan tak terduga. Anak usia dini akan memperbolehkan kebiasaan dengan apa yang mereka senangi untuk dilakukan, dan kapan waktu mereka untuk tidur. Semua kegiatan tersebut harus mereka pilih dan merupakan kebutuhan fisik mereka. (Martinis Yamin dan Jamilah Sabri Sanam: 2010). Dari pendapat Winnicot tersebut, sangat dimungkinkan sekali jika anak usia dini dapat memiliki kemandirian apabila diberikan pola asuh yang baik dari orang tuanya atau pengasuhnya sebagai pengganti. Sebagaimana pada awalnya bayi tidak bisa mandiri, mereka masih membutuhkan orangtua atau orang dewasa lainnya untuk mengurus kebutuhan mereka. Namun dengan semakin bertambahnya usia, mereka harus diajarkan bagaimana cara membentuk kemandirian. Sebenarnya, anak pada awal usia kehidupan sudah siap untuk memasuki tahapan kemandirian. Tahap ini layaknya menapaki tangga. Sejalan dengan (Tabi’in 2019)dalam menumbuhkan kemandirian anak diperlukan langkah-langkah yang tepat dan harus dipersiapkan dengan matang untuk membantu anak dalam mencapai kepribadian mandiri. Orang tua memiliki kewajiban untuk menstimulasi anak mandiri yang meliputi belajar berdiri, berjalan, bahkan membantunya agar tidak mengompol lagi. Hal ini penting sekali sebagai awal pembentukan kepribadian anak.

Untuk mendorong anak usia dini menuju ke kemandiriannya, orang tua dan guru perlu memberikan berbagai pilihan dan bila dimungkinkan sekaligus memberikan gambaran kemungkinan konsekuensi yang menyertai pilihan yang diambilnya. Dalam konteks lingkungan keluarga di rumah, orang tua diharapkan dapat lebih telaten dan sabar dengan cara memberikan berbagai pilihan dan membicarakannya secara saksama dengan anak-anak setiap kali mereka dihadapkan pada pembuatan keputusan-keputusan penting. Semua ini dilakukan agar anak dapat mengambil keputusan secara mandiri dan belajar dari konsekuensi yang ditimbulkan dari keputusan yang diambilnya. Sementara itu, di lingkungan Kelompok Bermain (KB) dan Taman Kanak-Kanak (TK), kemampuan anak usia dini perlu didengar dan diakomodasi oleh guru KB 
dan TK. Upaya itu diharapkan agar anak usia dini memiliki rasa percaya diri dalam mengambil keputusan secara mandiri (Agus Sujanto:2004).

Sikap kemandirian yang dimiliki oleh anak usia dini akan sangat bermanfaat bagi mereka dalam melakukan prosedur-prosedur keterampilan dan bergaul dengan orang lain. Kemandirian anak usia dini dalam melakukan prosedur-prosedur keterampilan merupakan kemampuan untuk melakukan aktivitas sederhana sehari-hari, seperti makan tanpa harus disuapi, mampu memakai kaos kaki dan baju sendiri, bisa buang air kecil/air besar sendiri, mampu memakai baju dan celana sendiri, dan dapat memilih mana bekal yang harus dibawanya saat belajar di KB maupun TK serta dapat merapikan mainannya sendiri. Sementara kemandirian anak usia dini dalam bergaul terwujud pada kemampuan mereka dalam memilih teman, keberanian mereka belajar di kelas tanpa ditemani orang tua, dan mau berbagi bekal/ jajan kepada temannya saat bermain.

\section{Panti Asuhan dalam Mengembangkan Kemandirian Anak}

Panti adalah rumah, tempat (kediaman), sedangkan asuhan adalah bimbingan, arti secara luas adalah adalah salah satu lembaga sosial yang mendidik dan membina anak yang memiliki masalah sosial seperti kemampuan ekonomi, kurangnya salah satu dari kepala keluarga atau keduanya, sehingga lingkungan keluarga tidak lagi dapat memberikan solusi terhadap permasalahan kehidupan yang membuat mereka merasa tidak memiliki masa depan yang jelas dikarenakan ketiadaan orang tua sendiri.

Untuk itu panti asuhan mempunyai peranan memfasilitasi anak-anak yatim, yatim piatu, dan anak-anak terlantar dalam mencari, memilih dan menentukan arah hidup yang tepat bagi bekal masa depan kehidupannya sebagai manusia yang bermartabat, berguna bagi diri, keluarga dan masyarakatnya kelak di hari nanti.

Panti asuhan mempunyai peran yang sangat penting dalam mengembangkan kemandirian anak yang sudah tidak mempunyai orang tua, Proses internalisasi mandiri dilaksanakan oleh panti asuhan tersebut kepada anak asuh melalui pengasuhan demokratis, komprehensif, yang meliputi atas proses pembiasaan dan pemberian teladan, komunikasi, memberikan kepercayaan dan menerapkan kedisiplinan kepada anak.

\section{Aspek kemandirian pada anak}

Dalam mengembangkan kemandirian pada anak-anak Panti Asuhan Dewi Aminah Kota Pekalongan melakukan beberapa langkah salah satunya yaitu :

a. Self Regulation

Anak-anak panti asuhan diarahkan untuk menyesuaikan tingkah laku mereka agar sesuai dengan agama dan dapat diterima oleh lingkungan sosial. Hal ini bertujuan untuk menghindari tingkah laku tingkah laku yang menurut akal pikiran tidak perlu dilakukan. Tingkah laku-tingkah laku yang menjadi rambu-rambu adanya self regulation di Panti Asuhan Dewi Amniah Kota Pekalongan yaitu dapat dapat menggunakan alat makan dengan baik dan benar, adab saat makan, saling berkomunikasi dengan baik, hormat menghormati serta mematuhi peraturan yang sudah dibuat oleh panti asuhan.

b. Self Control

Self control disini adalah anak-anak dapat mengendalikan tingkah laku mereka sesuai dengan norma yang ada, contoh self control ini yaitu anak-anak duduk ketika sedang makan dan minum, tidak suka marah-marah dan buang air kecil tidak dengan berdiri. 


\section{c. Self efficacy}

Anak-anak yang ada di panti asuhan Dewi Aminah diharapkan mampu mengerjakan tugas sehari-hari secara efektif meminimalisir bantuan dari teman yang ada. contoh dalam self efficacy adalah ketika anak-anak membersihkan mainan setelah selesai, mencuci piring setelah selesai makan, memakai baju sendiri.

d. Self determinatif

Pada Self Determination ini anak-anak diharapkan mampu menentukan dan mengambil keputusan sendiri dengan baik, contohnya anak-anak dapat memilih mainan mana yang akan digunakan, memilih baju dan menentukan kapan mereka harus belajar dan bermain.

\section{Pola asuh demokratis yang diterapkan pada anak usia dini di panti asuhan Dewi Aminah kota Pekalongan}

Pola asuh merupakan orang tua/pengasuh dalam berinteraksi yang meliputi pengasuh menunjukkan kekuasaan dan cara pengasuh memperhatikan keinginan anak.(Almutahar and Abao, n.d.) sejalan dengan (Muhadi 2015) Pola asuh yang diterapkan pengasuh dan pengurus panti berimplikasi pada sikap kemandirian anak. Pola asuh anak dalam penerapannya pengasuh memprioritaskan kepentingan anak tidak ragu-ragu dalam mengendalikan mereka. Dalam pola asuh anak, hal yang harus diperbaiki dalam mengasuh anak yaitu mengajarkan anak untuk lebih berinteraksi karena terciptanya kemandirian anak terjadi ketika. Pola asuh demokratis yang diterapkan di panti asuhan tersebut dalam upaya membentuk kemandirian anak usia dini meliputi:

\section{a. Pembiasaan}

Panti asuhan Dewi Aminah mempunyai program kegiatan pembelajaran yang menunjang pembiasan anak-anak panti, hal ini cukup berhasil diterapkan untuk membiasakan anak-anak dalam beraktivitas baik di dalam panti maupun di luar panti. Program kegiatan yang dilaksanakan yaitu berupa keseimbangan kemandirian dunia dan ukhrowi, yaitu pengasuh memberikan praktik dalam kehidupan tentang berikhtiar dalam kehidupan artinya dalam menjalani kehidupan tidak ada yang tiba-tiba atau instan, kemudian membiasakan penyelesaian masalah secara musyawarah, membiasakan merawat tanaman dan barang yang ada.

\section{b. Keteladanan}

Teladan merupakan bagian yang penting dalam proses pendidikan pada anak usia dini, seperti ungkapan "Like father like a son" begitu yang sering didengar sekalipun tidak semuanya benar namun pada umumnya akan melihat kebenaran pada salah satu ungkapan tersebut. Keteladanan mempunyai definisi yang sangat kompleks yaitu bagaimana dalam memberi contoh pada anak-anak, tentang sikap, perkataan, perbuatan yang sesuai dengan norma dan budaya yang ada. Orang tua harus menjadi contoh terhadap anak-anaknya tidak sekedar memberi contoh karena anak-anak akan melihat secara langsung apa yang dilakukan oleh orang tuanya tersebut. Selain itu keteladanan yang akan menjadi patokan anak selain orangtua adalah guru karena guru sangat erat berkaitan dengan anak didiknya dimana interaksi sosial dalam kegiatan pembelajaran terjadi dalam keseharian ketika anak-anak berada di lingkungan sekolah. 


\section{c. Kepercayaan}

Orang tua kadang ada yang khawatir terhadap anak-anaknya hal itu sangat wajar mengikat uisa mereka masih anak-anak akan tetapi orang tua juga harus memberikan kepercayaan karena seperti pepatah mengatakan "Trust is like a mirror, once its BROKEN you can never look at it the same again." Memberikan kepercayaan kepada anak seperti cermin jika cermin itu rusak maka tidak akan pernah bisa melihatnya sama seperti semula. Artinya orang tua harus melatih dan memberikan kepercayaan kepada anak supaya anak-anak percaya diri dalam mencoba hal-hal yang baru, jika kepercayaan tidak dibangun sejak kecil tentunya anak-anak akan akan termotivasi dalam melakukan hal-hal yang baru.

\section{d. Komunikasi}

Komunikasi merupakan hal penting dalam menjelaskan tentang kemandirian kepada anak dengan bahasa yang mudah dipahami oleh pengasuh. Pengasuh selalu memberikan nasihatnasihat kepada anak-anak dengan metode yang menyenangkan, misalnya melalui dongeng, bercerita yang tujuan intinya memberikan edukasi pada anak tentang kemandirian.

e. Disiplin

Kedisiplinan merupakan proses yang dilakukan oleh pengawasan dan bimbingan orang tua asuh yang konsisten. Dengan mengajarkan disiplin kepada anak sejak dini, berarti kita telah melatih anak untuk mandiri di masa datang dimana kunci kemandirian anak adalah sebenarnya ada di tangan orang tua dan guru.

\section{Upaya Mengembangkan Kemandirian Anak yang dilakukan panti asuhan}

Mengembangkan dan menumbuhkan kemandirian pada anak-anak panti asuhan pada hakikatnya adalah memberikan kesempatan untuk ikut serta terlibat dalam berbagai kegiatan yang ada. Semakin banyak ruang yang diberikan pada anak-anak panti asuhan tentunya akan memberikan dampak yang positif pada anak salah satunya anak akan semakin kreatif dalam mengembangkan skillnya sehingga anak-anak tersebut menjadi anak yang percaya diri. Upaya yang dilakukan dalam menumbuhkan kemandirian anak-anak panti asuhan Dewi Aminah dalam menumbuhkan kemandirian yaitu:

a. Anak-anak panti asuhan selalu diarahkan agar melakukan kegiatan-kegiatan yang ada di panti maupun di luar panti secara mandiri tentunya dimulai dari hal-hal yang sederhana karena mereka masih tergolong anak-anak yang butuh bimbingan dan pengasuhan, misalnya, mulai mandi sendiri kemudian menggosok gigi, makan dan ganti baju serta hal-hal yang sederhana lainnya.

b. Anak-anak panti asuhan selalu diberikan kesempatan untuk mengambil keputusan yang sederhana namun itu memiliki peran penting dalam menumbuhkan kemandirian anak yaitu dalam memakai sepatu secara berlahan-lahan dan memilih baju yang akan dipakai.

c. Memberikan kesempatan pada anak untuk bermain sendiri tanpa ada yang menemani hal ini tentunya melatih anak agar tidak memiliki rasa ketergantungan dengan pengasuh, disisi lain ini akan mengembangkan anak untuk mengasah gagasan atau ide dalam berpikir dalam melakukan permainan.

d. Memberikan kepercayaan pada anak untuk mengerjakan sesuatu sendiri walaupun terkadang masih kurang tepat atau salah dalam pengerjaannya, dari sini anak berlatih untuk memecahkan problem solving secara sederhana. 
e. Pengasuh selalu mendorong pada anak-anaknya untuk selalu mengungkapkan perasaan yang ada guna tercipta komunikasi dua arah antara anak dan pengasuh.

f. Pengasuh memberi kebebasan pada anak dalam memilih permainan yang ada supaya anakanak tidak memiliki ketergantungan dalam melakukan permainan.

g. Anak-anak di panti asuhan Dewi Aminah dilatih untuk bersosialisasi atau mensosialisasikan diri, hal ini agar anak belajar menghadapi problem sosial yang komplek, biasanya tatkala awal anak akan takut tentunya pengasuh mendampingi secara berlahan sehingga anak menjadi terbiasa.

h. Anak panti yang usianya sudah 7 tahun biasanya pengasuh mengajak untuk membantu di dapur bagi yang perempuan, bagi anak panti laki-laki membersihkan lantai, halaman dam merawat tanaman yang ada.

i. Anak panti asuhan dikenalkan dengan konsep waktu, mereka didorong untuk mengatur jadwal keseharian mulai bangun tidur, sekolah, mengaji dan belajar

j. Memberikan tanggung jawab kepada anak-anak panti serta mengetahui konsekuensinya secara sederhana. Contohnya tanggung jawab setelah bermain harus mengembalikan pada tempatnya. Hal ini guna membangun kedisiplinan anak.

k. Kesehatan dan kekuatan biasanya berkaitan juga dengan kemandirian, sehingga perlu memberikan menu yang sehat pada anak dan ajak anak untuk berolahraga atau melakukan aktivitas fisik.

Keberhasilan dalam menumbuhkan kemandirian ditunjukkan dengan terbentuknya kemandirian anak-anak di Panti Asuhan Dewi Aminah dengan baik (Ahmad Tabi'in 2016). Hal ini tidak terlepas karena adanya sebuah upaya yang sangat baik yang dilakukan pengasuh panti dalam menumbuhkan sikap kemandirian anak-anak yang ada di Panti Dewi Aminah. Pengasuh panti selalu memberikan motivasi yang berkaitan dengan keteladanan dalam kehidupan seharihari pada anak serta memberikan perhatian yang berkaitan dengan larangan-larangan yang mengakibatkan rasa kemandirian anak menjadi berkurang. Pola asuh demokratis menjadi faktor utama yang selalu diterapkan oleh panti asuhan tersebut dengan cara mengutamakan dialog pada anak-anak dengan bahasa yang santun dan mudah dipahami oleh anak serta selalu memberikan bimbingan pada anak-anak secara berkesinambungan disesuaikan dengan aspek psikologis anak. Pengasuh selalu memberikan motivasi pada anak untuk berekspresi dalam menjalankan kehidupan yang ada guna melatih kemandirian anak secara bertahap.

\section{Tahapan internalisasi kemandirian anak di Panti Asuhan Dewi Aminah Kota Pekalongan}

Upaya menumbuhkan kemandirian anak usia dini yang dilakukan oleh panti asuhan Dewi Aminah di kota Pekalongan meliputi tahapan-tahapan sebagai berikut:

\section{Tahap Transformasi Nilai}

Pada tahap ini pengasuh panti memberikan informasi mengenai nilai-nilai kemandirian kepada anak dengan memberikan contoh kehidupan orang lain yang selalu bergantung pada orang lain, disisi lain pengasuh juga memberikan contoh kehidupan orang-orang yang memiliki kemandirian hal ini penting diberikan kepada anak-anak panti asuhan guna menimbulkan rasa semangat motivasi anak dalam menumbuhkan kemandirian. Disini pengasuh Panti asuhan Dewi Aminah selalu mengulang-ulang cotoh kehidupan yang mandiri kepada anak karena dirasa sangat urgen untuk menjadikan anak-anak menjadi anak yang mandiri. Hal di atas merupakan salah satu 
rangkaian pembentukan sikap kemandirian anak usia dini di Panti Asuhan Dewi Aminah Kota Pekalongan yang berkaitan dengan tahap awal transformasi nilai.

\section{Tahap transaksi nilai}

Tahap transaksi nilai ini pengasuh panti asuhan Dewi Aminah tidak sekedar memberikan informasi yang terkait kemandirian saja, akan tetapi dalam hal transaksi nilai para pengasuh memberikan contoh dalam kehidupan sehari-hari serta terlibat aktif dalam kemandirian, harapan dari pengasuh nantinya anak akan mengikuti pola yang ada dari yang sudah dicontohkan dari pengasuh panti tersebut yaitu menerima dan mengaplikasikan kemandirian dalam kehidupan sehari-hari. Dengan seperti itu ada harapan besar anak mendapatkan contoh figure yang mandiri.

\section{Tahap transinternalisasi}

Pada tahap transinternalisasi pengasuh panti asuhan Dewi Aminah mempunyai harapan bahwa anak tidak memandang dari gaya atau penampilan fisik saja, akan tetapi membangun sikap dan mental psikologis anak agar mempunyai rasa percaya diri yang kuat dalam membangun kemandirian. Pada tahap transinternalisasiinipengasuh dan anak bersinergi dalam komunikasi secara aktif. Yang kemudian anak-anak mengasumsikan para pengasuh tidak hanya pintar alam memberikan arahan akan tetapi pengasuh selalu ikut serta dalam melakukan sesuatu berupa tindakan-tindakan nyata.

Tahapan pembentukan kemandirian yang dilakukan oleh pengelola dan stake holder Panti Asuhan Dewi Aminah meliputi tiga aspek tersebut, yaitu transformasi nilai, transaksi nilai dan trans integrasi nilai, hal ini di lakukan secara bertahap sampai pada kemudian hari anak mampu mengaplikasikan pada tatanan kehidupan sehari-hari. Hal itu tentunya tidaklah mudah dan mempunyai kesabaran yang besar, karena objeknya adalah anak-anak yang mempunyai kategori usia 4-6 tahun yang secara kemampuan harus sering diarahkan dan dibina.

\section{SIMPULAN}

Berdasarkan hasil penelitian dan pembahasan, maka dapat disimpulkan bahwa: anak-anak yang awal mula masuk ke panti asuhan masih seperti anak pada umumnya artinya anak-anak masih ingin diperhatikan karena terbiasa hidup dengan orang tua masing-masing sehingga anak belum bisa mandiri. Hal seperti itu dikarenakan pola asuh yang di lakukan oleh orang tua masingmasing kebanyakan tidak menggunakan pola asuh demokratis melainkan menggunakan pola asuh yang lain yang tidak mengajarkan anak untuk mandiri, Panti Asuhan Dewi Aminah Kota Pekalongan tentunya mempunyai Pola yang berbeda dalam mengasuh anak-anak nya yaitu menggunakan Pola Asuh Demokratis Sebagai Upaya Menumbuhkan Kemandirian Anak Usia Dini di Panti Asuhan Dewi Aminah Kota Pekalongan hasilnya adalah pola asuh yang digunakan oleh pengurus Panti Asuhan Dewi Aminah kota Pekalongan, menggunakan jenis pola asuh demokrasi yang mana ini dilakukan agar anak memiliki rasa tanggung jawab dalam melaksanakan aktivitas keseharian yang ada di panti asuhan tersebut. Panti Asuhan Dewi Aminah juga memberikan kebebasan dalam berinteraksi anak-anak panti baik di dalam lingkungan maupun di luar lingkungan dengan penuh tanggung jawab, apa yang mereka lakukan mempunyai konsekuensi-konsekuensi yang harus di pertanggung jawabkan. hal ini dilakukan supaya anak dapat mengekspresikan diri dan menambah wawasan. Sikap keteladanan dan cara pengasuhan dari pengurus dalam membina dan menumbuhkan sikap mandiri pada anak melalui pola asuh 
demokratis ini menjadi solusi penting dimana pola asuh dan keteladanan yang menjadi kunci menumbuhkan kemandirian anak yang ada di panti asuhan Dewi Aminah Kota Pekalongan. Pengguanaan pola asuh demokratis sangatlah cocok dalam mengembangkan anak pada perilaku mandiri. Terlihat dari hasil penelitian yang ada pengguanaan pola asuh tersebut dengan metode atau cara yang sederhana dan mudah dimengerti oleh anak dapat menumbuhkan sikap mandiri anak dalam aktivitas sehari-hari, yaitu anak dapat membersihkan tempat main setelah selesai bermain, anak mampu mandi sendiri tanpa bantuan orang tua, anak mampu memakai dan memilih baju sendiri dan hal-hal yang berkaitan dengan aktivitas sehari-hari anak.

\section{REFERENSI}

Agency, Beranda dan Tridhonanto, Al. 2014. Mengembangkan Pola Asub Demokratis. Jakarta: Gramedia.

Akmad Imam Muhadi. 2015. "Hubungan Pola Asuh Demokratis Terhadap Kemandirian Anak Di Taman Kanak -Kanak El-Hijaa Tambak Sari Surabaya.” Jumal Pendidikan Islam 4 (1): 17. Almutahar, Hasan, and Antonia Sasap Abao. n.d. "Pola Pengasuhan Anak Yatim Terlantar dan Kurang Mampu di Panti Asuhan Bunda Pengharapan (PABP) di Kecamatan Sungai Raya Kabupaten Kubu Raya,” 18. Jurnal Tesis PMIS-UNTAN-PSS-2014.

Anngreswari Ayu Dharmayanti dan Kwartarini Wahyu Yuniarti, 2006 . "Kemandirian Anak Usia 2,5 - 4 Tahun Ditinjau dari Tipe Keluarga dan Tipe Prasekolah," Jurnal sosiosain. Jakarta : Indonesia.

A Tabi'in,. 2017. "Pengelolaan Pendidikan Karakter Disiplin Anak Usia Dini Studi Kasus di AlMuna Islamic Preschool Semarang." AWLADY: Jurnal Pendidikan Anak 3 (1).

Ahmad. Tabi'in, 2016. "Membangun Kreativitas Anak Melalui Permainan Tradisional Jawa." MAGISTRA: Media Pengembangan Ilmu Pendidikan Dasar Dan Keislaman 7 (1).

Ahmad.Tabi'in, 2019. "Implementation of STEAM Method (Science, Technology, Engineering, Arts And Mathematics) for Early Childhood Developing in Kindergarten Mutiara Paradise Pekalongan" 02 (1): 14.

Al.,Tridhonanto. 2014. Mengembangkan Pola Asub Demokratis. Jakarta: PT Elex Media Komputindo.

Agus Sujanto, dkk, 2004. Psikologi Kepribadian, Jakarta: Bumi Aksara.

B. Mathew dan Michael Huberman Miles. 1992. Analisis Data Kualitatif Buku Sumber Tentang Metode-metode Baru. Jakarta: UIP.

Beti Septiari. 2012. Mencetak Balita Cerdas dan Pola Asub Orang Tua. Yogyakarta: Nusa Medika.

Depdiknas. Kamus Besar Bahasa Indonesia. edisi ketiga. Jakarta: Balai Pustaka.

Ervina and Ifdil Ifdil Rianti. 2018. "Kemandirian Anak Panti Asuhan." SCHOULID: Indonesian Journal of School Counseling 3 (2).

Fathi. B. 2011. Mendidik Anak dengan Al Quran Sejak Janin. Jakarta: Grasindo.

Fitr Sriyani and Sariah Sariah. 2019. "Pola Asuh Orang Tua Terhadap Karakter Anak Di Raudhatul Athfal Al-Fityah Pekanbaru." KINDERGARTEN: Journal of Islamic Early Childhood Education 1 (2).

Harbeng Masni, n.d. "Peran Pola Asuh Demokratis Orangtua Terhadap Pengembangan Potensi Diri Dan Kreativitas Siswa," 17.

Idris Meity H., 2012. Pola Asub Anak, Melejitkan Potensi dan Prestasi Sejak Usia Dini. Jakarta: Luxima. 
Martinis Yamin dan Sabri Sanam Jamilah. 2010. Panduan Pendidikan Anak. Usia Dini (Jakarta: GP Press.

Muhadi. 2015. Hubungan Pola Asuh DemokratisTerhadap Kemandirian Anak di Taman KanakKanak El- Hija Tambak Sari Surabaya. Jurnal Pendidikan Islam. 4(1):43- 44.

Lexy J Moleong. 2005. Metodologi Penelitian Kualitatif, Bandung: Remaja Rosdakarya.

Meity Idris H.dkk. 2014. Menjadi Pendidik yang Menyenangkan dan Professional Implementasi pada Pendidikan Anak Usia Dini. Jakarta: LuximaIroh Siti Zahroh dan Ismia Unasiansari, 2011. Komunikasi dalam Pengasuban (Kementerian Pendidikan dan Kebudayaan Republik Indonesia.

Novan Ardy Wiyani \& Barnawi, 2014. Format PAUD: Konsep, Karakteristik, \& Implementasi Pendidikan Anak Usia Dini. Jogjakarta: Ar-Ruzz Media.

Restu Rina Tri Lestari, Arbaiyah Prantiasih, and Nuruddin Hady. n.d. "Peranan Panti Asuhan Dalam Membina Moral Anak Asuh Di Panti Asuhan Roudlatul Jannah SelopuroBLITAR," 12.

Rony Kountur. 2005. Metode Penelitian untuk Penulisan Skripsi dan tesis. Jakarta: PPM.

Siti Umairoh, 2018. "Perbedaan Pola Asuh Orang Tua Terhadap Kemandirian Anak.". Jurnal Ilmiah Tumbuh Kembang Anak Usia Dini Golden Age.September 3 (3): 9.

Suryana. 2007. Tahap-tahapan Penelitian Kualitatif Mata Kuliah Analisis Data Kualitatif. Bandung: Universitas Pendidikan Indonesia.

Syamsu Yusuf LN. 2012. Psikologi Perkembangan Anak dan Remaja. Bandung: PT. Remaja Rosdakarya.

Wiyani. 2013. Bina Karakter Anak Usia Dini. Yogyakarta: AR-RUZZ Media. 